\title{
ETHNOBOTANY AND POPULAR CULTURE IN THE USE OF PLANTS IN SETTLEMENTS ON THE SOUTHERN EDGE OF SOUTHERN PANTANAL MATO GROSSO
}

\author{
ETNOBÔTANICA E A CULTURA POPULAR NO USO DE PLANTAS EM \\ ASSENTAMENTOS NA BORDA SUL DO PANTANAL SUL-MATO-GROSSENSE
}

\author{
Jorge de Souza PINTO ${ }^{1,2}$; Ademir Kleber Morbeck de OLIVEIRA ${ }^{3}$; Valtecir FERNANDES ${ }^{2}$; \\ Rosemary MATIAS ${ }^{3}$ \\ 1. Federal University of Mato Grosso do Sul, Campus do Pantanal, Campo Grande, MS, Brazil; 2. Postgraduate Program in \\ Environment and Regional Development, University Anhanguera-Uniderp, Campo Grande, MS, Brazil; 3. University Anhanguera- \\ Uniderp, Campo Grande, MS, Brazil. akmorbeckoliveira@gmail.com
}

\begin{abstract}
Popular culture and its relationship with plants has been the subject of scientific studies and brought significant contributions to science. In this assessment, developed in two settlements in Corumbá and Ladário, Mato Grosso do Sul, was evaluated the use of plants for medicinal purposes. A structured questionnaire was administered to 10 raizeiros, residents of the area, asking which plants were used by them, their methods of preparation and therapeutic indications. Fifty-five plants from 28 families were catalogued among plants native to the region and of exotic and/or external origin, only $40 \%$ were native. The predominant form of use is tea (41 citations), followed by infusion (16 citations). The most used parts are the leaves, with 43 citations, followed by flowers (6 citations). There is a predominance of the type of problem for which the plant is used, with 12 citations for problems in the respiratory system, followed by eight for kidney and liver problems and seven for the stomach. What has been found is a wide diversity of species used for the most different problems, indicating the importance of the use of medicinal plants for the communities studied.
\end{abstract}

KEYWORDS: Medicinal Plants. Native Species. Popular Culture.

\section{INTRODUCTION}

Understanding the treatment of diseases by the use of plants is to capture a cultural aspect that is socially propagated by learning from experiences. When based on adequate scientific premises, it can become an alternative way of discussing the functionality of medicinal plants, thus gaining information that can be compiled into collective scientific knowledge. According to Vila Verde et al. (2003), folk medicine has been offering an increasing contribution to science, due to a range of medical knowledge and practices of empirical character, influenced by the sociocultural, economic and physical context in which they are placed.

Several authors, for example Guarim Neto (2006), Kunwar et al. (2006), Oliveira et al. (2011) and Penido et al. (2016), have described the use of plants for the treatment of various diseases. This kind of knowledge is often the only treatment option for many communities and ethnic groups, traditional medicine in poor countries is the most affordable and practical and, in some cases, the only treatment available for the population. Cunha and Bortolotto (2011) and Kumar (2016) write that the recognition and recovery of local knowledge about medicinal plants are essential in rural communities, because home remedies are an alternative cure, often the only possible one due to lack of other resources for health care.

Authors like Maciel et al. (2002) and Kumar (2016) report that the use of medicinal plants, used to combat different diseases, is as old as the human species living in the community, and today, in the poorest regions of the country and even on the outskirts of large cities, these plants are sold at fairs and found in the backyards of homes.

According to the World Health Organization, approximately $90 \%$ of the population in developing countries depend on traditional medicine in regard to primary health care. In some industrialized countries, the use of traditional medicine products is also significant, as Canada and Italy, with 70 to $90 \%$ of the population using resources of traditional medicine with the name of complementary, alternative or unconventional (WHO, 2011). Similarly in Brazil, about $82 \%$ of the population uses medicinal herbal products in their health care (RODRIGUES; DE SIMONI, 2010).

Furthermore, dissemination of medicinal plants, through the knowledge of traditional peoples, is an important tool in the preservation of the cultural richness of different regions (OLIVEIRA et al., 2011; ARAÚJO et al., 2016).

In Brazil, a country of continental dimensions and a rich and diverse flora, the use of 
herbs for medicinal purposes is widespread, reinforced by cultural differences arising from colonization by Europeans and Africans and from traditional indigenous knowledge (GOMES et al., 2008; ARAÚJO et al., 2016). This combination of distinct cultures, associated with high biodiversity, generated a traditional medicine based on plants and different methods of treatments in several Brazilian regions, as cited by Guarim Neto and Morais (2003), Souza (2007), Silva and Proença (2008), Zucchi et al. (2013), Pires et al. (2014) and Pereira et al. (2016).

Among the different biomes, the Pantanal is a floodplain located mostly in the states of Mato Grosso and Mato Grosso do Sul, bordering Bolivia and Paraguay, with the occurrence of plants in different locations, such as the Chaco, Cerrado, Amazon and Atlantic Forest (POTT et al., 2011). The plain is composed of sub-regions, with vegetation characteristics associated with different environmental factors such as soil type and level of flooding, for example, influencing the distribution of species, adapted to intermittent cycles of flood and drought in the region (OLIVEIRA et al., 2012).

There is a great diversity of plant species, with medicinal use by local populations known as pantaneiros (swamp-dwellers), a native population with great cultural importance, adapted to the intermittent cycles of flood and drought of the region, according to ethnobotanic studies as reported for example by Pott and Pott $(1994,2000)$, Cunha and Bortolotto (2011) and Oliveira et al. (2011).

The procedures for correct collection and use of medicinal plants usually belong to restricted population groups, such as the raizeiros (root-users: usually people with little formal education who possess knowledge hereditarily passed down by their parents or other people on the use of plants for the treatment of diseases) and others, commonly elderly people who have received information from their parents and grandparents (GUARIM NETO, 2006). Usually these groups are small and threatened by environmental changes that alter their lifestyle and culture, making the recovery of their knowledge fundamental to salvaging traditions that may be lost and/or extinct.

Thus, the ethnobotanical approach the study of the use of medicinal plants by a given population, and is a useful apparatus in the development of phytochemical and pharmacological studies, since it has already been established by continuous use. For these reasons and taking into account the information gaps in ethnobotanical knowledge of raizeiros living in rural communities in the municipalities of Corumbá and Ladário, this study aimed to identify parts of the plants used in folk medicine at these regions.

\section{MATERIAL AND METHODS}

The study was conducted with 10 raizeiros resident in two rural settlements, including four in Taquaral, Corumbá municipality, established in 1991 and located about $15 \mathrm{~km}$ from the city, roughly between the coordinates $19^{\circ} 02^{\prime}$ to $19^{\circ} 10^{\prime}$ South and $57^{\circ} 37^{\prime}$ to $57^{\circ} 44^{\prime}$ West of Greenwich and a total area of $10013.24 \mathrm{ha}$; and six in the settlement known as A72, municipality of Ladário, implemented in 1999, with total area of 2341.2996 ha, between coordinates $19^{\circ} 03^{\prime}$ to $19^{\circ} 07^{\prime}$ South and $57^{\circ} 33^{\prime}$ to $57^{\circ} 36^{\prime}$ West. Both are located on the edge of the southern Pantanal, Mato Grosso do Sul, Brazil.

A structured questionnaire was applied between December and March, 2014, with the raizeiros, residents of the area. It had been formulated for the interviewees to answer which plants were used by them (popular name), their methods of preparation and what the therapeutic indications were. The study was approved by the Ethics Committee in Research of the University Anhanguera-Uniderp (statement number 542 779). To define who would be interviewed, as a selection criterion, the parameter was that people should have been born in the Pantanal region or have spent most of their life in the place (more than 20 years) using the flora as part of their routine to solve health problems, both their own and those of their neighbors.

To avoid embarrassment, respondents were free to speak in accordance their own situation, with interviews conducted using the regional language, taking place in the area of the property of the settler, where he demonstrated the origin and existence of plants owned and/or cultivated. The raizeiro could also point out the plants in the environment that characterized the region of rural properties, allowing him to provide explanations about the various therapeutic uses of identified species and where their knowledge came from. The species mentioned, when necessary, were collected and transported at Herbarium COR (Universidade Federal de Mato Grosso do Sul) for identification and deposit, classified using the Angiosperm Phylogeny Group (APG II, 2003; APG III, 2009), with species cited by Sano and Almeida (1998) and Pott and Pott (1994), considered native to the area. 


\section{RESULTS AND DISCUSSION}

In this study 28 plant families were identified, containing 55 plant species recognized as having medicinal use in the region (Table 1).

Different researchers in different regions report studies on the use of medicinal plants in the states of Mato Grosso and Mato Grosso do Sul. Guarim Neto (2006), in a compilation of previous research, reported 56 medicinal plants used in traditional medicine by pantaneiros. Oliveira et al. (2011), working on the Rio Negro region, cited 48 species. Duarte and Pasa (2016), working on the São Benedito region, Poconé, 29 species. Berg and Silva (1988), in a survey conducted on a larger number of locations, in the cities of Campo Grande, and also Aquidauana and Miranda, Pantanal, listed 104 species considered as medicinal plants.

Table 1. Family, scientific and common name of medicinal plants, parts used ( $L=$ Leaves; $B=B a r k ; F l=$ Flowers; $\mathrm{S}=$ Seeds; $\mathrm{Rh}=$ Rhizome; $\mathrm{R}=$ Roots; $\mathrm{C}=\mathrm{Culm} ; \mathrm{G}=\mathrm{Gum}$ ), mode of use (ch= tea; in = in natura; $\mathrm{m}=$ maceration; $\mathrm{d}=$ decoction; $\mathrm{i}=$ infusion; $\mathrm{s}=$ juice; $\mathrm{x}=$ syrup) and therapeutic indication, identified by raizeiros in the settlements A72, Ladário and Taquaral, Corumbá, Mato Grosso do Sul, Brazil

\begin{tabular}{|c|c|c|c|c|c|}
\hline Family & Scientific and common name & $\begin{array}{l}\text { Parts } \\
\text { used }\end{array}$ & $\begin{array}{l}\text { Mode } \\
\text { of use }\end{array}$ & Indication & $\begin{array}{l}\text { Native } \\
\text { species }\end{array}$ \\
\hline Alismataceae & $\begin{array}{l}\text { Echinodorus grandiflorus Riche } \mathrm{x} \\
\text { Engelm (Chapéu-de-couro) }\end{array}$ & $\mathrm{L}$ & $\mathrm{ch}$ & $\begin{array}{l}\text { Renal diseases, } \\
\text { diuretic }\end{array}$ & $\mathrm{X}$ \\
\hline Anacardiaceae & $\begin{array}{c}\text { Myracrodruon urundeuva Engl } \\
\text { (Aroeira) }\end{array}$ & B & ch & $\begin{array}{l}\text { Liver ailments, bone } \\
\text { fractures }\end{array}$ & $\mathrm{x}$ \\
\hline \multirow[t]{3}{*}{ Apiaceae } & $\begin{array}{c}\text { Petroselinum crispum (Mill.) } \\
\text { (Salsa) }\end{array}$ & $\mathrm{L}$ & in & Anemia, arthritis & \\
\hline & Anethum graveolens L. (Endro) & $\begin{array}{l}\mathrm{L}, \mathrm{Fl}, \\
\mathrm{S}\end{array}$ & $\mathrm{d}, \mathrm{m}, \mathrm{i}$ & $\begin{array}{l}\text { Toothache, liver } \\
\text { ailments, cold }\end{array}$ & \\
\hline & $\begin{array}{l}\text { Foeniculum vulgare Mill. } \\
\text { (Funcho) }\end{array}$ & $\mathrm{S}$ & ch & $\begin{array}{l}\text { Heartburn, bronchitis, } \\
\text { flu }\end{array}$ & \\
\hline \multirow[t]{8}{*}{ Asteraceae } & Arthemisia absinthium L. (Losna) & $\mathrm{L}, \mathrm{Fl}$ & $\mathrm{i}, \mathrm{d}, \mathrm{x}$ & $\begin{array}{l}\text { Runny nose, parasites, } \\
\text { vomiting }\end{array}$ & \\
\hline & $\begin{array}{c}\text { Cymbopogon citratus (DC) } \\
\text { (Capim-Santo) }\end{array}$ & $\begin{array}{l}\mathrm{L}, \\
\mathrm{Rh}\end{array}$ & $\mathrm{ch}, \mathrm{d}, \mathrm{i}$ & Anxiety & \\
\hline & $\begin{array}{l}\text { Solidago microglossa DC. } \\
\text { (Arnica brasileira) }\end{array}$ & $\mathrm{L}, \mathrm{Fl}$ & $\mathrm{ch}$ & $\begin{array}{l}\text { Wounds, rheumatism, } \\
\text { cough }\end{array}$ & \\
\hline & $\begin{array}{c}\text { Tagete erecta L. (Cravo-de- } \\
\text { defunto) }\end{array}$ & $\mathrm{L}, \mathrm{Fl}$ & $\mathrm{i}, \mathrm{x}$ & Insecticide, bronchitis & \\
\hline & $\begin{array}{c}\text { Baccharis trimera (Less.) DC. } \\
\text { (Carqueja) }\end{array}$ & $\mathrm{S}$ & $\mathrm{ch}$ & $\begin{array}{c}\text { Inflammation of the } \\
\text { urinary tract, obesity, } \\
\text { diabetes }\end{array}$ & $\mathrm{x}$ \\
\hline & $\begin{array}{c}\text { Mikania laevigata Schultz. Bip. } \\
\text { Ex Baker (Guaco) }\end{array}$ & $\mathrm{L}$ & $\mathrm{ch}, \mathrm{i}$ & Flu, cough & \\
\hline & $\begin{array}{l}\text { Achillea millefolium } \mathrm{L} . \\
\text { (Pronto-alívio) }\end{array}$ & $\begin{array}{c}\mathrm{L}, \mathrm{S}, \\
\mathrm{Fl}, \\
\mathrm{Rh}\end{array}$ & $\begin{array}{l}\text { in, ch, } \\
\mathrm{x}, \mathrm{m}\end{array}$ & $\begin{array}{l}\text { Soothing, circulatory } \\
\text { problems }\end{array}$ & \\
\hline & $\begin{array}{l}\text { Vernonia polyanthes Less. (Assa- } \\
\text { peixe branco) }\end{array}$ & $\mathrm{L}, \mathrm{R}$ & $\mathrm{ch}, \mathrm{d}$ & $\begin{array}{l}\text { Bronchitis, kidney } \\
\text { stone }\end{array}$ & $\mathrm{x}$ \\
\hline \multirow[t]{2}{*}{ Bignoniaceae } & $\begin{array}{l}\text { Handroanthus impetiginosus } \\
\text { (Mart. ex DC.) Mattos (Ipê-rosa) }\end{array}$ & $\mathrm{L}, \mathrm{B}$ & ch & Colitis, diarrheia & $\mathrm{x}$ \\
\hline & $\begin{array}{l}\text { Tabebuia aurea (Silva Manso) } \\
\text { Benth \& Hook (Paratudo) }\end{array}$ & L, B & ch & $\begin{array}{l}\text { Anemia, stomach } \\
\text { pains }\end{array}$ & $\mathrm{x}$ \\
\hline Bixaceae & Bixa orellana L. (Coloral) & $\begin{array}{c}\text { Fr, } S, \\
\text { R }\end{array}$ & $\mathrm{i}, \mathrm{d}, \mathrm{r}$ & $\begin{array}{l}\text { Cholesterol control, } \\
\text { diabetes, insect } \\
\text { repellent }\end{array}$ & \\
\hline Brassicaceae & Brassica oleracea L. (Couve) & $\mathrm{L}$ & in & $\begin{array}{l}\text { Ulcer healing, } \\
\text { inflammatory diseases }\end{array}$ & \\
\hline Caprifiliaceae & Sambucus nigras L. (Sabugueiro) & $\mathrm{Fl}$ & $\mathrm{ch}$ & Chickenpox, & \\
\hline
\end{tabular}




\begin{tabular}{|c|c|c|c|c|c|}
\hline & & & & & \\
\hline \multirow[b]{2}{*}{ Celastraceae } & \multirow[b]{2}{*}{$\begin{array}{c}\text { Maytenus ilicifolia (Schrad.) } \\
\text { (Cancorosa) }\end{array}$} & \multirow[b]{2}{*}{$\begin{array}{l}\mathrm{L}, \mathrm{B} \\
\mathrm{R}\end{array}$} & \multicolumn{3}{|c|}{$\begin{array}{l}\text { bronchitis, throat } \\
\text { infections }\end{array}$} \\
\hline & & & $\mathrm{ch}, \mathrm{i}, \mathrm{d}$ & $\begin{array}{l}\text { Against ulcers, blood } \\
\text { clearance }\end{array}$ & $\mathrm{x}$ \\
\hline Chenopodiaceae & $\begin{array}{l}\text { Chenopodium ambrosioides L. } \\
\text { (Erva-de-Santa-Maria) }\end{array}$ & $\mathrm{L}$ & $\mathrm{s}, \mathrm{i}$ & Parasites, healing & $\mathrm{x}$ \\
\hline Ciperaceae & $\begin{array}{c}\text { Kyllinga odorata Vahl. (Capim- } \\
\text { cidreira) }\end{array}$ & $\begin{array}{c}\mathrm{L}, \mathrm{C} \\
\mathrm{Rh}\end{array}$ & $\mathrm{ch}$ & Soothing & \\
\hline Crassulaceae & $\begin{array}{l}\text { Kalanchoe pinnata (Lam.) Pers } \\
\text { (Folha-da-fortuna) }\end{array}$ & $\mathrm{L}$ & $\mathrm{m}$, in & $\begin{array}{l}\text { Bruises, whooping } \\
\text { cough }\end{array}$ & \\
\hline Cucurbitaceae & $\begin{array}{c}\text { Momordica charantia L. (Melão- } \\
\text { de-São-Caetano) }\end{array}$ & $\mathrm{L}$ & $\mathrm{ch}, \mathrm{m}$ & $\begin{array}{l}\text { Earache, loss of vision, } \\
\text { bile-duct infections }\end{array}$ & $\mathrm{x}$ \\
\hline \multirow[t]{3}{*}{ Euphorbiaceae } & $\begin{array}{c}\text { Jatropha molissima (Pohl) Baill } \\
\text { (Pinhão-bravo) }\end{array}$ & $\mathrm{L}$ & $\mathrm{ch}$ & Antifungal & \\
\hline & $\begin{array}{l}\text { Phyllanthus niruri L. (Quebra- } \\
\text { pedra) }\end{array}$ & $\mathrm{L}, \mathrm{R}$ & $\mathrm{ch}$ & Kidney stones & $\mathrm{x}$ \\
\hline & $\begin{array}{l}\text { Euphorbia hirta L. (Erva-de- } \\
\text { Santa-Luzia) }\end{array}$ & $\mathrm{L}, \mathrm{Fl}$ & $\mathrm{ch}$ & Asthma & $\mathrm{x}$ \\
\hline \multirow[t]{3}{*}{ Fabaceae } & $\begin{array}{l}\text { Anadenanthera macrocarpa } \\
\text { (Benth.) (Angico-rosa) }\end{array}$ & $\mathrm{G}, \mathrm{B}$ & $\mathrm{x}, \mathrm{i}, \mathrm{d}$ & $\begin{array}{l}\text { Dysentery, } \\
\text { hemorrhage }\end{array}$ & $\mathrm{x}$ \\
\hline & Cassia occidentalis L. (Fedegoso) & $\begin{array}{l}\mathrm{L}, \mathrm{B} \\
\mathrm{S}, \mathrm{R}\end{array}$ & $\mathrm{ch}, \mathrm{m}$ & Parasites, healing & $\mathrm{x}$ \\
\hline & Hymenaea courbaril L. (Jatobá) & $\mathrm{G}, \mathrm{B}$ & $\mathrm{x}, \mathrm{i}, \mathrm{d}$ & Bronchitis, cough & $\mathrm{x}$ \\
\hline Faboideae & Dipteryx alata Vog. (Baru) & Fr & in & Parasites & $\mathrm{x}$ \\
\hline Geraniaceae & $\begin{array}{c}\text { Pelargonium graveolens L. Her } \\
\text { (Malva) }\end{array}$ & $\mathrm{L}, \mathrm{R}$ & $\mathrm{ch}$ & Soothing & $\mathrm{x}$ \\
\hline \multirow[t]{6}{*}{ Lamiaceae } & $\begin{array}{l}\text { Plectranthus barbatus Andr. } \\
\text { (Boldo-do-Chile) }\end{array}$ & $\mathrm{L}, \mathrm{R}$ & $\mathrm{ch}$ & $\begin{array}{l}\text { Stomatitis, liver } \\
\text { ailments }\end{array}$ & \\
\hline & $\begin{array}{c}\text { Ocimum americanum } \mathrm{L} . \\
\text { (Manjerona) }\end{array}$ & $\begin{array}{l}\mathrm{L}, \mathrm{Fl}, \\
\mathrm{S}\end{array}$ & $\mathrm{ch}, \mathrm{i}, \mathrm{d}$ & Respiratory diseases & \\
\hline & $\begin{array}{c}\text { Leonotis nepetifolia L. (Cordão- } \\
\text { de-São-Francisco) }\end{array}$ & $\mathrm{L}$ & $\mathrm{ch}$ & Uric acid, fever & \\
\hline & Ocimum basilicum L. (Alfavaca) & $\begin{array}{l}\mathrm{L}, \mathrm{Fl}, \\
\mathrm{R}\end{array}$ & $\mathrm{ch}, \mathrm{i}, \mathrm{d}$ & $\begin{array}{l}\text { Cold sore, kidney } \\
\text { problens }\end{array}$ & \\
\hline & $\begin{array}{l}\text { Mentha piperita } \mathrm{L} . \\
\text { (Hortelanzinho) }\end{array}$ & $\mathrm{L}$ & $\mathrm{ch}$ & Gallstones, sore throat & \\
\hline & $\begin{array}{l}\text { Rosmarinus officinalis L. } \\
\text { (Alecrim) }\end{array}$ & $\mathrm{L}, \mathrm{Fl}$ & $\mathrm{ch}, \mathrm{i}, \mathrm{x}$ & $\begin{array}{l}\text { Infection of the } \\
\text { stomach }\end{array}$ & \\
\hline Liliaceae & Aloe vera $\mathrm{L}$. (Babosa) & $\mathrm{L}$ & $\mathrm{c}$ & Ulcer, gastritis, burns & \\
\hline \multirow[t]{2}{*}{ Malpighiaceae } & $\begin{array}{l}\text { Heteropterys tomentosa A. Juss } \\
\text { (Nó-de-cachorro) }\end{array}$ & $\mathrm{B}, \mathrm{R}$ & ch, d & $\begin{array}{l}\text { Aphrodisiac, nervous } \\
\text { exhaustion }\end{array}$ & $\mathrm{x}$ \\
\hline & $\begin{array}{l}\text { Jatropha elliptica Müll. Arg } \\
\text { (Purga-de-lagarto) }\end{array}$ & $\mathrm{R}$ & $\mathrm{ch}$ & Antifungal & $\mathrm{x}$ \\
\hline \multirow[t]{2}{*}{ Malvaceae } & $\begin{array}{l}\text { Hibiscus rosa-sinensis } \mathrm{L} . \\
\text { (Hibisco) }\end{array}$ & $\mathrm{L}, \mathrm{Fl}$ & $\mathrm{ch}$, in & Laxative & \\
\hline & $\begin{array}{l}\text { Althaea officinalis L. } \\
\text { (Malva-branca) }\end{array}$ & $\begin{array}{l}\mathrm{L}, \mathrm{Fl} \\
\mathrm{R}\end{array}$ & $\begin{array}{l}\mathrm{ch}, \mathrm{i} \\
\mathrm{d}, \mathrm{m}\end{array}$ & $\begin{array}{l}\text { Wounds, gangrene, } \\
\text { sunburn }\end{array}$ & $\mathrm{x}$ \\
\hline \multirow[t]{3}{*}{ Myrtaceae } & $\begin{array}{l}\text { Eugenia jambolana Lam. } \\
\text { (Jamelão) }\end{array}$ & $\mathrm{L}, \mathrm{Fr}$ & $\begin{array}{l}\text { ch, i, } \\
\text { in }\end{array}$ & Cholesterol control & \\
\hline & Psidium guajava L. (Goiaba) & $\mathrm{L}$ & $\mathrm{ch}$ & Dysentery, diarrheia & \\
\hline & Eugenia uniflora L. (Pitanga) & $\mathrm{L}, \mathrm{Fr}$ & ch, in & $\begin{array}{l}\text { Disorders of the liver, } \\
\text { menstrual cramps }\end{array}$ & \\
\hline Rubiaceae & Morinda citrifolea L. (Noni) & $\mathrm{L}, \mathrm{Fr}$ & $\mathrm{ch}$, in & $\begin{array}{l}\text { Diabetes, arthritis, } \\
\text { hypertension }\end{array}$ & \\
\hline
\end{tabular}




\begin{tabular}{|c|c|c|c|c|c|}
\hline \multirow[t]{3}{*}{ Rutaceae } & Citrus sinensis Osbeck (Laranja) & $\begin{array}{l}\text { L, } \\
\text { Fr, Fl }\end{array}$ & $\mathrm{ch}$, in & $\begin{array}{l}\text { Flu, cough, muscle } \\
\text { contraction }\end{array}$ & \\
\hline & Ruta graveolens L. (Arruda) & $\mathrm{L}, \mathrm{Fl}$ & $\mathrm{ch}, \mathrm{i}, \mathrm{d}$ & $\begin{array}{l}\text { Parasites, liver } \\
\text { ailments }\end{array}$ & \\
\hline & Citrus limon (L.) Burm (Limão) & $\begin{array}{l}\mathrm{L}, \mathrm{Fl} \\
\mathrm{Fr}\end{array}$ & $\mathrm{ch}$, in & Flu, cough & \\
\hline \multirow[t]{2}{*}{ Solanaceae } & $\begin{array}{c}\text { Solanum viarum Dunal (Joá- } \\
\text { amarelo) }\end{array}$ & $\begin{array}{l}\mathrm{L}, \\
\text { Fr, R }\end{array}$ & $\mathrm{ch}$ & Soothing, diuretic & $\mathrm{x}$ \\
\hline & $\begin{array}{l}\text { Solanum paniculatum } \mathrm{L} . \\
\text { (Jurubeba) }\end{array}$ & Fr & in & Liver ailments, fever & $\mathrm{x}$ \\
\hline Umbellifera & Pimpinella anisum L. (Erva-doce) & Fr & $\mathrm{ch}$ & Stomach acidity & \\
\hline Verbenaceae & $\begin{array}{c}\text { Stachytarpheta jamaicensis (L.) } \\
\text { Vahl (Gervão) }\end{array}$ & $\mathrm{L}, \mathrm{Fl}$ & $\mathrm{i}$ & Parasites, bronchitis & \\
\hline \multirow[t]{2}{*}{ Zingiberaceae } & Alpinia speciosa Schum (Colônia) & $\begin{array}{l}\mathrm{L}, \\
\mathrm{Rh}\end{array}$ & $\mathrm{ch}$ & Diuretic, cardiac tonic & \\
\hline & $\begin{array}{c}\text { Costus spiralis (Jacq.) Rosae } \\
\text { (Cana-do-Brejo) }\end{array}$ & $\begin{array}{l}\mathrm{L}, \\
\mathrm{Rh}\end{array}$ & $\mathrm{ch}$ & $\begin{array}{c}\text { Venereal diseases, } \\
\text { inflammation of the } \\
\text { kidneys }\end{array}$ & $\mathrm{x}$ \\
\hline
\end{tabular}

The number of species found in this study was similar to the species described by Guarim Neto (2006) and Oliveira et al. (2011), who studied in smaller geographic areas, indicating that greater regional coverage may include new species. As a result, of the 55 species recorded in the study, 33 are exotic (60\%), belonging to 19 families (Figure 1), such as M. citrifolea (Noni), observed in Taquaral settlement and originally from Southeast Asia.

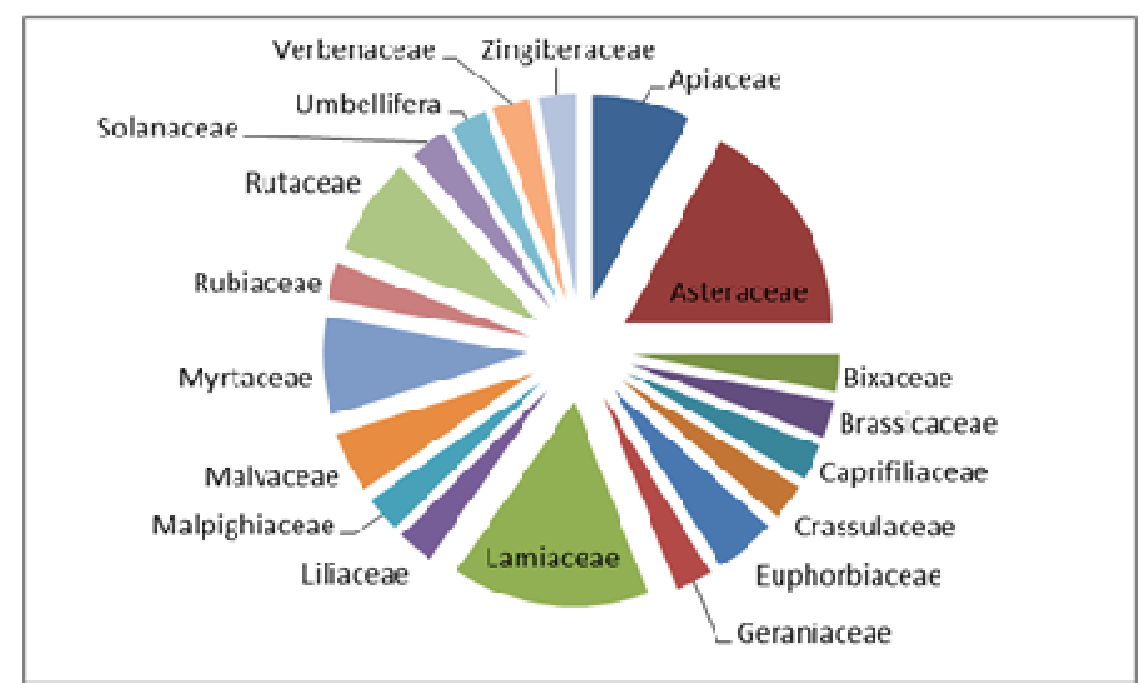

Figure 1. Ethnobotanical survey of families of exotic plants cultivated and/or used in settlements, Ladário A72 and Corumbá - Taquaral, Mato Grosso do Sul.

The data gathered suggest that although the interviewees had lived for more than 20 years in the region (or had never left the state of Mato Grosso do Sul), influence arises from the origin of some individuals and their cultural background, given that many continue with their customs and cultural traditions of using plants from their places of origin, predominantly the south and northeast of the country. They have thus ended up importing many exotic species to the biome in the region, and these have adapted and are now part of the routine of communities, such as fennel ( $F$. vulgare) and lemongrass (C. citratus).

An action was observed in the region, which may increase the loss of local knowledge: this involves initiatives from government agencies to develop projects to encourage the gardens and plantations of medicinal herbs in the settlements, with the purpose of generating income. This action further weakens the scarce knowledge of vegetation and plants from the Cerrado and Pantanal with medicinal use, because it encourages the cultivation of species that do not exist at the site, since these 
have a higher sale value, distancing the settlers from the potential of the local flora, both for use and for preservation.

However, Bortolotto (2007) comments that people select certain species to aid in their survival, diversifying the landscape with the introduction of species from other locations. This assertion is supported by Bennett and Prance (2000), describing the importance of the species used by indigenous and mestizo people from the northern region of South America, where many of these plants have been introduced after European colonization, for various purposes such as food, ornaments or medical purposes.

The Asteraceae family has the largest number of exotic species, eight, followed by Lamiaceae, with six. Among the species cited for these two families, there are several already established in folk medicine, such as wormwood ( $A$. absinthium), lemongrass (C. citratus), arnicabrasileira (S. microglossa), marigold ( $T$. erecta), carqueja ( $B$. trimera), guaco (M. glomerata), assapeixe $(V$. polysphaera), boldo-do-Chile $(P$. barbatus), marjoram (O. americanum), basil $(O$. basilicum), mint (M. piperita) and rosemary ( $R$. officinalis), indicating that some species have been accepted in various Brazilian regions.

These two families together account for $36.8 \%$ of the species (over one third) cited, showing that both families are widely used in folk medicine. According to Fabri et al. (2011), the Asteraceae family is known to possess therapeutic and aromatic properties, besides being used for cosmetic products, with different authors reporting the medicinal use of its species, such as Benedek et al. (2007) and Jeon et al. (2008). As for the Lamiaceae family, according to Fenner et al. (2006), there are many popular accounts of the use of different species in the treatment of respiratory tract infections, skin diseases and wounds, in addition to use as an antimicrobial and antiseptic.

On the other hand, 16 families are represented in a single species, totaling $57.1 \%$ (Alismataceae, Anacardiaceae, Bixaceae, Brassicaceae, Caprifiliaceae, Celastraceae, Chenopodiaceae, Ciperaceae, Crassulaceae, Cucurbitaceae, Faboideae, Geraniaceae, Liliaceae, Rubiaceae, Umbellifera and Verbenaceae). This indicates that there is a diversity of families used, despite the concentration of species in only two families.

Work developed by Oliveira et al. (2011) indicated that $39.6 \%$ of the species mentioned by the inhabitants of the Pantanal Negro and raizeiros from the cities of Miranda and Aquidauna are exotic, such as boldo-do-Chile ( $P$. barbatus), a species suitable for upset stomach and as a digestive. Cunha and Bortolotto (2011), in the municipality of Anastácio-MS, where about $43 \%$ of the species are exotic, obtained a similar result. The data obtained for Corumbá and Ladário indicated a greater influence of the urban environment on the use of medicinal plants and the gradual loss of connection with the rural environment and its medicinal species. Perhaps this situation can be the result of greater access to information and allopathic medicines, because Corumbá is a larger city and located relatively close to the settlements.

In relation to the collected species, 22 are native $(40 \%)$, representing 14 families $(50 \%)$ (Figure 2), indicating that more of half of the species and half of families are exotic.

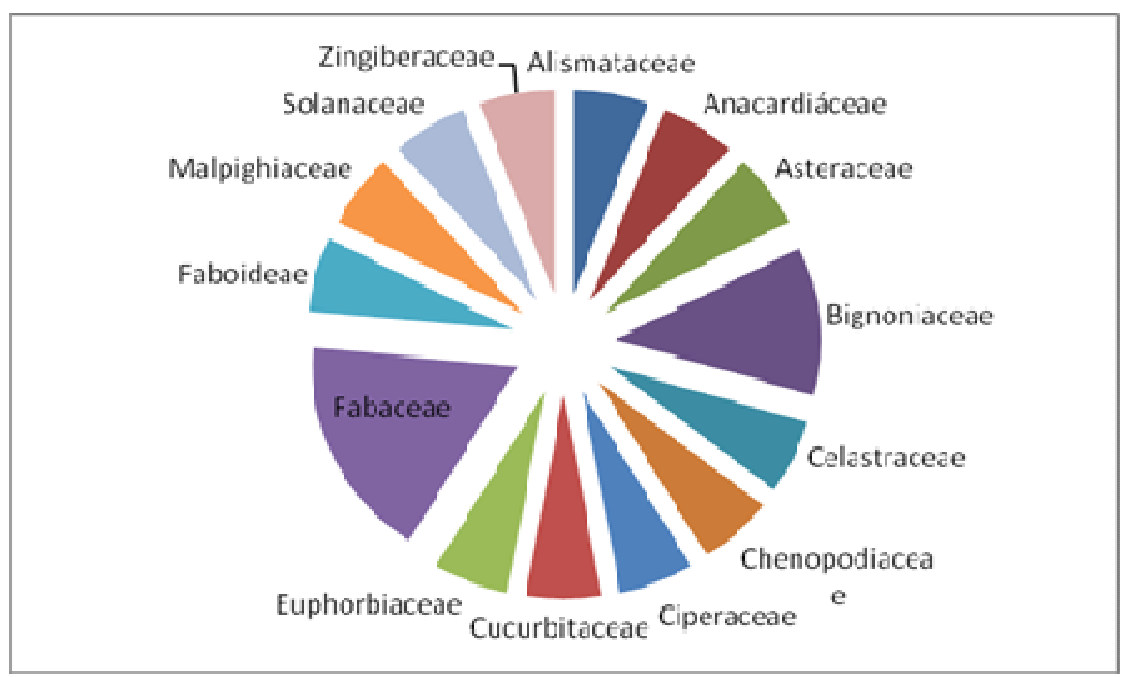

Figure 2. Ethnobotanical survey of families of native plants cultivated and/or used in settlements, Ladário A72 and Corumbá - Taquaral, Mato Grosso do Sul. 
For native species, the number of plants per family with medical use is much lower, highlighting the Fabaceae family, with three species. The Fabaceae Lindl or Leguminosae Adans is considered the most representative botanical family in Brazil, found in all biomes and, according to Guarim and Moraes Neto (2003), Penido et al. (2016) and Souza et al. (2016), it is one of the families most used by the native populations.

The predominant form of use (Table 1) is tea, with 41 citations, followed by infusion with 16; the use of plants by means of teas is also reported as prevalent in other regions, as recorded by Pinto et al. (2006) in Itacaré-Bahia, Santos et al. (2008) in Vargem Grande-SP, Cunha and Bortolotto (2011) in Anastácio-MS, Barbosa et al. (2015) in Alto Boa Vista-MT and Penido et al. (2016) in Imperatriz, Maranhão. Normally, the use of teas is the most readily available method for the user. Unlike the research reported by Cunha and Bortolotto (2011), in these areas it is not common to use certain plant species in the preparation of tereré and chimarrão, regional drinks mainly originating from Mato Grosso do Sul and Rio Grande do Sul and widely consumed in the region. As well the preparation of garrafada (potions) was not mentioned by interviewees. Garrafada is the combination of different species with similar active ingredients for the treatment of certain diseases, sweetened with sugar or honey and sometimes with the addition of wine or cachaça and stored in bottles.

The plant part that is most used is the leaves, with 42 citations, followed by flowers (16 species), roots (12 species), fruits (9 species), bark (8 species) and in sequence, with a smaller number, are the seeds, rhizomes, stems and the gum released by two species, angico-rosa (A. macrocarpa) and jatobá (H. courbaril). In other studies conducted, such as Schardong and Cervi (2000), Medeiros et al. (2004), Pilla et al. (2006), Cunha and Bortolotto (2011) and Penido et al. (2016), the leaves were used by most of the population. The increased use of the leaves may be related to the ease of collection, since these, depending on the species, may be present all year and after collection, return to sprout, making their use sustainable.

There is also a predominance of the type of problem for which the plant is used with 12 citations for problems in the respiratory system and eight species described for the treatment of the renal and hepatic system, followed by seven for stomach problems. The higher rate of utilization for respiratory diseases is related to common problems of pneumonia and influenza that can lead to death, particularly in the elderly and children
(FRANCISCO et al., 2004). Similar results, with the use of plants to combat respiratory diseases, such as influenza, have also been reported by Pilla et al. (2006), Silva and Proença (2008), Cunha and Bortolotto (2011), Barbosa et al. (2015) and Souza et al. (2016).

In relation to obtaining knowledge about medicinal plants, most interviewees gave their source of information as mostly being passed on by family and friends, indicating a form of horizontal transmission of knowledge. Cunha and Bortolotto (2011) reported similar results, with knowledge being obtained through acquaintances, a result similar to that reported by Amorin et al. (2013) in Bahia and Duarte and Pasa (2016) in Poconé, Mato Grosso, in a rural community of afro descendant.

Eyssartier et al. (2008) report the exchange of information during adult life as an example of a source of information and knowledge, and according to Cunha and Bortolotto (2011) and Duarte and Pasa (2016), social relations allow the transmission of knowledge between people, passed on to children, siblings, neighbors and acquaintances, verbally or by watching practical experience.

The results show a potential for further studies aimed at increasing the knowledge on the use of species (ethnobotany), given that in the region knowledge on the medicinal properties of plants is still nascent, and the development of research in this line may generate systemic benefits in the long term. New research could also strengthen the science-society relationship, to provide cooperation in a system of education for environmental appreciation and preservation of the environment by means of sustainable use.

\section{CONCLUSIONS}

The predominant form of plant use is tea, followed by infusion. The most used parts are the leaves, followed by flowers. And the predominant use is for problems in the respiratory system followed by kidney and liver problems.

There is a wide diversity of plant species used for the most different problems, indicating the importance of the use of medicinal plants for the communities studied. However, there is a loss of knowledge of plants and their therapeutic purposes, bringing consequences for the preservation of the environment, such as the Pantanal, where the plant species have many as yet unresearched active ingredients and benefits that are unknown by the pharmaceutical industry, and which may in the future aid human health. 


\section{ACKNOWLEDGMENTS}

The authors are grateful to the National Council for Scientific and Technological Development $(\mathrm{CNPq})$ for providing the research grant (PQ2) and the Coordination for the Improvement of Higher Education Personnel (Capes), for the master's and doctoral scholarship. We would also like to thank the
PINTO, J. S. et al.

Pantanal Research Centre (CPP), National Institute of Science and Technology in the Wetlands (INAU), National Council for Scientific and Technological Development (CNPq/MCT), Foundation to Support the Development of Education, Science and Technology of State of Mato Grosso do Sul (FUNDECT) and the University AnhangueraUniderp for funding the GIP project (Interdisciplinary Research Group).

RESUMO: A cultura popular e sua relação com as plantas tem sido objeto de estudos científicos e trazido contribuições significativas para a ciência. Nesta pesquisa desenvolvida em dois assentamentos nos municípios de Corumbá e Ladário, Mato Grosso do Sul, foi avaliada a utilização de plantas para fins medicinais. Um questionário estruturado foi aplicado a 10 raizeiros, residentes nos locais, buscando identificar quais plantas eram utilizadas, seus métodos de preparação e indicações terapêuticas. Foram catalogadas 55 plantas de 28 famílias, entre nativas da região e exóticas e/ou de origem externa, sendo que apenas $40 \%$ eram nativas. A forma de uso predominante é o chá (41 citações), seguida por infusão (16 citações). As partes mais utilizadas são as folhas, com 43 citações, seguida pelas flores (16 citações). Há uma predominância quanto ao tipo de problema para qual a planta é usada, com 12 citações para problemas no sistema respiratório, seguido por oito para problemas renais e hepáticos e sete relacionadas ao estômago. Verificou-se uma ampla diversidade de espécies utilizadas, para os mais diferentes problemas, indicando a importância da utilização das plantas medicinais para as comunidades estudadas.

PALAVRAS-CHAVE: Plantas Medicinais. Espécies Nativas. Cultura Popular.

\section{REFERENCES}

AMORIM, M. M.; TOMAZI, L.; SILVA, R. A. A.; GESTINARI, R. S.; FIGUEIREDO, T. B. Avaliação das condições habitacionais e de saúde da comunidade quilombola Boqueirão, Bahia, Brasil. Bioscience Journal, Uberlândia, v. 29, n. 4, p. 1049-1057, 2013.

APG II. Angiosperm Phylogeny Group. An update of the Angiosperm Phylogeny Group classification for the orders and families of flowering plants: APG II. Botanical Journal of the Linnean Society, London, v. 141, n. 4, p. 399-436, 2003.

APG III. Angiosperm Phylogeny Group. An update of the Angiosperm Phylogeny Group classification for the orders and families of flowering plants: APG III. Botanical Journal of the Linnean Society, London, v. 161, n. 2, p. 105-121, 2009.

ARAÚJO, T. A. S.; MELO, J. G.; FERREIRA JÚNIOR, W. S.; ALBUQUERQUE, U. P. Medicinal plants. In: ALBUQUERQUE, U. P.; ALVES, R. R. N. (Edts.). Introduction to ethnobiology. Springer International Publishing, 2016. p. 143-149. https://doi.org/10.1007/978-3-319-28155-1_22

BARBOSA, A. A.; SANTOS, W. R.; FERREIRA, A. F. S.; SILVA, N. D.; RAMOS, P. R. Cultivo e uso de plantas medicinais pelos moradores de Alto Boa Vista - MT. Cadernos de Agroecologia, Recife, v. 10, n. 3, p. $1-5,2015$.

BENEDEK, B.; KOPP, B.; MELZIG, M. F. Achillea millefolium L. s.I. - Is the antiinflamatory activity mediated by protease inhibition? Journal of Ethnopharmacology, Amsterdam, v. 113, n. 2, p. 312-317, 2007. https://doi.org/10.1016/j.jep.2007.06.014

BENNETT, B. C.; PRANCE, G. T. Introduced plants in the indigenous pharmacopoeia of Northen South America. Economic Botany, New York, v. 54, n. 1, p. 90-102, 2000. https://doi.org/10.1007/BF02866603 
BERG, M. E.; SILVA, M. H. L. Contribuição à flora medicinal de Mato Grosso do Sul. Acta Amazonica, Manaus, v. 18, v. 1-2, p. 9-22, 1988.

BORTOlOtTO, I. M. Simpósio Plantas, Povos e Paisagens: Estudos de Casos no Pantanal Sul-MatoGrossense. In: BARBOSA, L. M.; SANTOS JUNIOR, N. A. (Orgs.). A botânica no Brasil: pesquisa, ensino e políticas públicas ambientais. 1ed. São Paulo: Sociedade Botânica do Brasil, 2007. p. 223-227.

CUNHA, A. S.; BORTOLOTTO, I. M. Etnobotânica de plantas medicinais no Assentamento Monjolinho, município de Anastácio, Mato Grosso do Sul, Brasil. Acta Botanica Brasilica, Feira de Santana, v. 25, n. 3, p. 685-698, 2011. https://doi.org/10.1590/S0102-33062011000300022

DUARTE. G. S. D.; PASA, M. C. Agrobiodiversidade e a etnobotânica na comunidade São Benedito, Poconé, Mato Grosso, Brasil. INTERAÇÕES, Campo Grande, v. 17, n. 2, p. 247-256, 2016.

EYSSARTIER, C.; LADIO, A. H.; LOZADA, M. Cultural transmission of traditional knowledge in two populations of North-western Patagonia. Journal of Ethnobiology and Ethnomedicine, London, v. 4, n. 1, p. 1-8, 2008. https://doi.org/10.1186/1746-4269-4-25

FABRI, R. L.; NOGUEIRA, M. S.; DUTRA, L. B.; BOUZADA, M. L. M.; SCIO, E. Potencial antioxidante e ntimicrobiano de espécies da família Asteraceae. Revista Brasileira de Plantas Medicinais, Botucatu, v. 13, n. 2, p. 183-189, 2011.

FENNER, R.; BETTI, A. H.; MENTZ, L. A.; RATES, S. M. K. Plants with potential antifungal activity employed in Brazilian folk medicine. Revista Brasileira de Ciências Farmacêuticas, São Paulo, v. 42, n. 3, p. 369-394, 2006. https://doi.org/10.1590/S1516-93322006000300007

FRANCISCO, P. M. S. B.; DNALISIO, M. R.; LATTORRE, M. R. D. O. Internações por doenças respiratórias em idosos e a intervenção vacinal contra influenza no Estado de São Paulo. Revista Brasileira de Epidemiologia, São Paulo, v. 7, n. 2, p. 220-227, 2004. https://doi.org/10.1590/S1415-790X2004000200011

GOMES, H. H. S.; DANTAS, I. C.; CATÃO, M. H. C. V. Plantas medicinais: sua utilização nos terreiros de umbanda e candomblé na zona leste de cidade de Campina Grande-Pb. Revista de Biologia e Farmácia, João Pessoa, v. 3, n. 1, p. 110-129, 2008.

GUARIM NETO, G.; MORAIS, R. G. Recursos medicinais de espécies do Cerrado de Mato Grosso: Um estudo bibliográfico. Acta Botanica Brasilica, São Paulo, v. 17, n.4, p. 561-584, 2003.

GUARIM NETO, G. O saber tradicional pantaneiro: as plantas medicinais e a educação ambiental. Revista Eletrônica do Mestrado em Educação Ambiental, Porto Alegre, v. 17, p. 71-89, 2006. https://doi.org/10.1590/s0102-33062003000400009

JEON, H. J.; KANG, H. J.; JUNG, H. J.; KANG, Y. S.; LIM, C. J.; KIM, Y. M.; PARK, E. H. Antiinflamatory activity of Taraxacum officinale. Journal of Ethnopharmacology, Amsterdam, v. 115, n. 1, p. 82-88, 2008. https://doi.org/10.1016/j.jep.2007.09.006

KUMAR, M. Rural communities and ethno medicinal plants, uses and their conservation. Medicinal \& Aromatic Plants, s S3: e003, p. 1-2, 2016.

KUNWAR, R. M.; NEPAL, B. K.; KSHHETRI, H. B.; RAI, S. K.; BUSSMANN, R. W. Ethnomedicine in Himalaya: a case study from Dolpa, Humla, Jumla and Mustang districts of Nepal. Journal of Ethnobiology and Ethnomedicine, London, v. 2, n. 27, p. 1-6, 2006.

MACIEL, M. A. M.; PINTO, A. C.; VEIGA JUNIOR, V. F. Plantas medicinais: a necessidade de estudos multidisciplinares. Química Nova, São Paulo, v. 25, n. 3, p. 429-438, 2002. https://doi.org/10.1590/S010040422002000300016 
MEDEIROS, M. F. T.; FONSECA, V. S.; ANDREATA, R. H. P. Plantas medicinais e seus usos pelos sitiantes da Reserva Rio das Pedras, Mangaratiba, RJ, Brasil. Acta Botanica Brasilica, São Paulo, v. 18, n. 2, p. 391 399, 2004. https://doi.org/10.1590/S0102-33062004000200019

OLIVEIRA, A. K. M.; OLIVEIRA, N. A.; RESENDE, U. M.; MARTINS, P. F. R. B. Ethnobotany and traditional edicine of the inhabitants of the Pantanal Negro sub-region and the raizeiros of Miranda and Aquidauna, Mato Grosso do Sul, Brazil. Brazilian Journal of Biology, São Carlos, v. 71, n. 1, p. 283-289, 2011. https://doi.org/10.1590/S1519-69842011000200007

OLIVEIRA, A. K. M.; PAGOTTO, T. C. S.; PARANHOS FILHO, A. C.; MOREIRA, E. S. O desmatamento no Pantanal: causas e consequências. In. ALVES, G. L.; MERCANTE, M.A.; FAVERO, S. Pantanal SulMato-Grossense: ameaças e propostas. Campinas: Editores Associados; São Paulo: Universidade Anhanguera-Uniderp, 2012. p. 29-58.

PENIDO, A. B.; MORAIS, S. M.; RIBEIRO, A. B.; SILVA, A. Z. Ethnobotanical study of medicinal plants in Imperatriz, State of Maranhão, Northeastern Brazil. Acta Amazonica, Manaus, v. 46, n. 4, p. 345-354, 2016. https://doi.org/10.1590/1809-4392201600584

PEREIRA, K. C.; MEIRELES, V. J. S.; MEIRELES, M. P. A. Uso medicinal de plantas na comunidade de Recanto do Prato, Inhuma-Piauí. Revista Espacios, v. 37, n. 5, p. 14, 2016.

PILLA, M. A. C.; AMOROZO, M. C. M.; FURLAN, A. Obtenção e uso das plantas medicinais no distrito de Martim Francisco, Município de Mogi-Mirim, SP, Brasil. Acta Botanica Brasilica, São Paulo, v. 20, n. 4, p. 789-802, 2006. https://doi.org/10.1590/S0102-33062006000400005

PINTO, E. P. P.; AMOROZO, M. C. M.; FURLAN, A. Conhecimento popular sobre plantas medicinais em comunidades rurais de Mata atlântica - Itacaré, BA, Brasil. Acta Botanica Brasilica, São Paulo, v. 20, n. 4, p. 751-762, 2006. https://doi.org/10.1590/S0102-33062006000400001

PIRES, I. F. B.; SOUZA, A. A.; FEITOSA, M. H. A.; COSTA, S. M. Plantas medicinais como opção terapêutica em comunidade de Montes Claros, Minas Gerais, Brasil. Revista Brasileira de Plantas Medicinais, Campinas, v. 16, n. 2, supl. I, p. 426-433, 2014.

POTT, A.; POTT, V. J. Plantas do Pantanal. Brasília: EMBRAPA, 1994. 320p.

POTT, V. J.; POTT, A. Plantas aquáticas do Pantanal. Brasília: Embrapa Comunicação para Transferência de Tecnologia, 2000. 404p.

POTT, A.; OLIVEIRA, A. K. M.; DAMASCENO-JUNIOR, G. A.; SILVA, J. S. Plant diversity of the Pantanal wetland. Brazilian Journal of Biology, São Carlos, v. 71, n. 1, p. 265-273, 2011.

RODRIGUES, A. G.; DE SIMONI, C. Plantas medicinais no contexto de políticas públicas. Informe Agropecuário, Belo Horizonte, v. 31, n. 255, p. 7-12, 2010.

SANTOS, J. F. L.; AMOROZO, M. C. M.; MING, L. C. Uso de plantas medicinais na comunidade rural da Vargem Grande, município de Natividade da Serra, SP. Revista Brasileira de Plantas Medicinais, Botucatu, v. 10, n. 3 , p. $67-81,2008$.

SANO, S. M.; ALMEIDA, S. M. Cerrado: ambiente e flora. Planaltina: Embrapa-CPAC, 1998. 556p.

SCHARDONG, R. M. F.; CERVI, A. C. Estudos etnobotânicos das plantas de uso medicinal e místico na comunidade de São Benedito, bairro São Francisco, Campo Grande, MS, Brasil. Acta Biológica Paranaense, Curitiba, v. 29, n. 1-4, p. 187-217, 2000. https://doi.org/10.5380/abpr.v29i0.591 
SILVA, C. S. P.; PROENÇA, C. E. B. Uso e disponibilidade de recursos medicinais no município de Ouro Verde de Goiás, GO, Brasil. Acta Botanica Brasilica, São Paulo, v. 22, n. 2, p. 481-492, 2008. https://doi.org/10.1590/S0102-33062008000200016

SOUZA, L. F. Recursos vegetais usados na medicina tradicional do Cerrado (comunidade de Baús, Acorizal, MT, Brasil). Revista Brasileira de Plantas Medicinais, Botucatu, v. 9, n. 4, p. 44-54, 2007. https://doi.org/10.21472/bjbs.030507

SOUZA, A. S.; SOUZA, A. P. B.; LUCENA, R. F. P. Relative importance of medicinal plants in the Semi-Arid Region of Paraíba: a case study in the Municipality of Congo (Paraíba, Northeast Brazil). Brazilian Journal of Biological Sciences, João Pessoa, v. 3, n. 5, p. 83-96, 2016.

VILA VERDE, G. M.; PAULA, J. R.; CARNEIRO, D. M. Levantamento etnobotânico das plantas medicinais do cerrado utilizadas pela população de Mossâmedes (GO). Revista Brasileira de Farmacognosia, Curitiba, v. 13, p. 64-66, 2003. https://doi.org/10.1590/S0102-695X2003000300024

WHO. World Health Organization. The world medicines situation 2011: traditional medicines: global situation, issues and challenges. Geneva: WHO, 2011. 28p.

ZUCCHI, M. R.; OLIVEIRA JÚNIOR, V. F.; GUSSONI, M. A.; SILVA, M. B.; SILVA, F. C.; MARQUES, N. E. Levantamento etnobotânico de plantas medicinais na cidade de Ipameri - GO. Revista Brasileira de Plantas Medicinais, Campinas, v. 15, n. 2, p. 273-279, 2013. https://doi.org/10.1590/S1516-

05722013000200016 